\title{
Alternative, environmental friendly opportunities in agricultural technologies
}

\author{
Zoltán MAYER - Viktor SZENTPÉTERI - Ákos JUHÁSZ - Katalin POSTA \\ Institute of Genetics, Microbiology and Biotechnology, Department of Microbiology and Environmental \\ Toxicology, 2100 Gödöllő, Páter Károly st. 1.; E-mail: Mayer.Zoltan@mkk.szie.hu
}

Keywords: plant, mycorrhiza, bacteria, micropropagation

\section{Introduction}

The project starts with basic research aimed at exploring the bacterial and fungal communities of the symbiosis of acacia (Robinia pseudoacacia) natural habitats using genetic technologies. The next step is to investigate what microbial communities settle on intensively cultivated acacia and poplar plantations, how they affect the different nutrients. AM fungi and bacterial inoculation have the potential to be a useful biotechnological tool for benefiting plant development and health, increasing plant defense mechanisms to alleviate different stress effects during the method of micropropagation and pot experiment.

\section{Materials and methods}

Plants were transplanted to four types of substrate (heat sterilized peat, gardening pearlt, rock wool, sterilized sand) and inoculated with bacterial inoculant and arbuscular mycorrhizal fungi and their combinations. The used bacterial inoculant is a commercial product. Mycorrhizal fungi in product Symbivit ${ }^{\circledR}$ (mixture of G. intraradices BEG140, G. mosseae BEG95, G. etunicatum BEG92, G. claroideum BEG96, G. microaggregatum BEG56, G. geosporum BEG199) produced by Symbiom Ltd. (Lanskroun, Czech Republic; www.symbiom.cz) was applied at $15 \mathrm{~g}$ of inoculum (consisting of 80 propagules $\mathrm{g}^{-1}$ ) per seedling into the planting hole.

FDA hydrolysis activity test was used to determination of total microbial activity (Schnürer and Rosswall, 1982). In order to determine the enzyme activity of peroxidase (PER) and polyphenol oxidase (PPO) plant extract was prepared using $0.2 \mathrm{~g}$ fresh plant leaves in Tris- $\mathrm{HCl}$ (3 ml; $50 \mathrm{mM}$; pH 7.8); polyvinylpyrrolidone-K $25(7.5 \%(\mathrm{w} / \mathrm{v})$ and EDTA-Na $(1 \mathrm{mM})$ buffer. Peroxidase enzyme activities are performed by Rathmell and Sequeira (1974), the change in absorbance is observed at $436 \mathrm{~nm}$ wavelength. The concentration of polyphenol oxidase enzyme - more specifically the degree of the formation of quinone compounds - was carried out by Fehrmann and Dimond (1967). The change in absorbance was monitored at $400 \mathrm{~nm}$ for 10 minutes. Plant extract for catalase (CAT) and glutathione S-transferase (GST) protocol was prepared using $0.2 \mathrm{~g}$ fresh leaves in $1.2 \mathrm{ml} 0.2 \mathrm{M}$ sodium phosphate buffer ( $\mathrm{pH} 7.8,0.1 \mathrm{mM}$ EDTA). The catalase enzyme activity was measured by the method of Aebi (1984), based on the dissociation ability of hydrogen peroxide. The change of absorbance was followed at $240 \mathrm{~nm}$ wavelength for 5 minutes. Glutathione S-transferase enzyme activities were measured using Glutathione S-transferase (GST) Assay Kit (Sigma-Aldrich-Merck, Darmstadt, Germany) established on the method of Habig et al. (1974). The concentration of total soluble protein in plant extract solution was determined using Bradford reagent, bovine serum albumin as a standard (Bradford, 1976). Plants were harvested and growth, fresh and dry weight of shoots and roots were estimated. 


\section{Results and discussion}

Following the inoculation of micro-seeded seedlings, it was observed that the inoculation of the arbuscular mycorrhizal fungi and the treatment of the bacterial inoculant in such juvenile state of the seedlings were subjected as stress. During the favorable effects of the inoculation and the initial phase of colonization, does not prevail in this early stage of plants to the extent of the later stages. Based on plant weight measurements, the perlite was the most suitable among the different cultivating media for plants inoculated with arbuscular mycorrhizal fungi and in combination with bacterial. In addition, the control plant seedlings showed the highest growth strength in the perlite growing medium.

The highest microbiology activity was measured in combination of bacterial and fungal inoculant, which is due to the fact that arbuscular mycorrhizal fungi and soil bacterial are also actively involved in increasing the microbiological activity of the soil. The measured enzymes showed various activity depending on the substrate medium, inoculation and the stage of the plants.

\section{Conclusions}

Our results suggest that AM fungi inoculation combinated with bacterial inoculant could take part in the alleviation processes caused by the stress of propagation and transplantation. However, these mechanisms are influenced by the age of the plants which probably justified by energy considerations.

\section{Acknowledgement}

This research was supported by Development and Innovation Fund of Hungary (20171.3.1-VKE-2017-00022).

\section{References}

Aebi, H. (1984): Catalase in vitro. Method. Enzymol., 105: 121-126.

Bradford, M. (1976): A rapid and sensitive method for the quantitation of microgram quantities of protein utilizing the principle of protein-dye binding. Analytical Biochemistry. 72 : 248-254. https://doi.org/10.1006/ abio. 1976.9999

Fehrmann H., Dimond A.E. (1967): Peroxidase activity and phytophthora resistance in different organs of the potato plant. Phytopathology. 57:69-72.

Habig, W.H., Pabst, M.J., Jakoby, W.B. (1974): Glutathione S-transferases the first enzymatic step in mercapturic acid formation. The Journal of Biological Chemistry. 249: 7130-7139.

Rathmell W.G., Sequeira L. (1974): Soluble peroxidase in fluid from the intercellular spaces of tobacco leaves. Plant Physiology. 53:317-318. https://doi.org/10.1104/pp.53.2.317

Schnürer J., Rosswall T. (1982): Fluorescein Diacetate Hydrolysis as a Measure of Total Microbial Activity in Soil and Litter. Applied and Environmental Microbiology. 43 (6), 1258. 